Figures and Letters. A Methodological Remark on the Inscriptions in Catalan Romanesque Mural Paintings

\title{
Vincent Debiais
}

Centre national de la recherche scientifique.

Centre d'études supérieures de civilisation médiévale.

Poitiers, France

e-mail: vincent.debiais@univ-poitiers.fr

Received: 20 Oct. 2015 | Revised: 2 Nov. 2015 | Accepted: 14 Dec. 2015 | Available online: 21 Dec. 2015 | doi: 10.1344/Svmma2015.6.12

\section{Resume}

Les inscriptions dans le corpus de la peinture murale catalane sont très nombreuses. Il constitue un vaste laboratoire d'étude pour comprendre comment l'inscription prend place dans le décor peint et comment les signes iconiques et alphabétiques interagissent à l'échelle du bâtiment, éventuellement dans la mise en scène du rituel liturgique. Cet article n'entend pas dresser le corpus complet des inscriptions peintes romanes de Catalogne; il envisage plutôt de comment les relations texte/image montrent une écriture active pour produire du sens dans la dynamique générale de l'édifice (dynamique liturgique, communautaire, symbolique, etc.). En reposant la question de la «fonction » des inscriptions et en étudiant quelques inscriptions peintes, cette communication espère promouvoir une lecture plus fine des textes épigraphiques de la peinture catalane, plus respectueuse des relations originales qu'entretiennent, dans la création artistique médiévale, l'écriture et l'image.

Mots Clés: épigraphie médiévale, peintures murales, art roman, art catalan, liturgie, paléographie, inscription, iconographie, Bible.

\begin{abstract}
Inscriptions are numerous in the corpus of Catalan mural paintings, which thus provides a vast laboratory to understand the place of inscriptions in painted decoration and how iconic and alphabetic signs interact throughout the building, and possibly in the staging of the liturgical ritual. This article does not intend to draw up a complete corpus of Romanesque painted inscriptions in Catalonia; rather, it aims to consider how the relationship between text and image show the active role of writing in the production of meaning within the general dynamics of the building (liturgical, communal, symbolic dynamic, etc.). Raising the question of the "function" of inscriptions and studying some painted inscriptions, this paper hopes to promote a closer reading of the epigraphic texts of Catalan painting; one that is more respectful of the original relationships existing between writing and image in medieval artistic creations.
\end{abstract}

Key Words: medieval epigraphy, mural paintings, Romanesque art, Catalan art, liturgy, palaeography, inscription, iconography, Bible. 
Anyone who has visited the medieval halls of the National Museum of Catalan art can testify to the richness of its Romanesque collections; anyone who has wandered through the halls devoted to mural painting can attest to the originality of the themes represented and the existence of a style that is specific to Catalonia, and was especially active in the first half of the $12^{\text {th }}$ century; anyone who has had the chance to visit the Romanesque churches from which these paintings come, in the heart of the Pyrenees, can only admire the cultural and constructive dynamism of Catalonia in the central period of the Middle Ages. ${ }^{1}$

Among these visitors, how many have noted, however, the omnipresence of writing in the painted decorations? Have they noted that the Christ of Sant Climent de Taüll is flanked by the letters alpha and omega in a monumental format? Have they noticed that the Apostolic College at his feet is identified by a long inscription across the apse (Fig. 1: general view of the apse)? Have they deciphered the text placed near the Crucifixion of Sant Pere de Sorpe? Have they spotted that the archangels of Santa Maria d'Àneu are accompanied by the text of the triple Sanctus of the beginning of the Canon of the Mass? One can legitimately doubt it. The museum labels describing the apses reconstructed in the MNAC in Barcelona never mention the inscriptions in the paintings and, to date, there is no comprehensive study on the writings in Catalan mural paintings.

The purpose of this short article is not to address what must be considered a real historiographical gap. ${ }^{2}$ Its goal is rather to point some avenues of research in this area and some of the specific features of writing in the painted image in medieval epigraphic production, ${ }^{3}$ especially within the rich corpus of Romanesque mural paintings in Catalonia.

Epigraphy has long restricted its attention to the inscriptions engraved on hard and durable materials, in line with what the ancient documentation has passed on to posterity and therefore has neglected the texts painted throughout the Middle Ages, whether perennially, inside buildings, or provisionally, on wooden signs and tables. ${ }^{4}$ Furthermore, the study of painted decorations has often "forgotten" to describe, analyse, and reproduce the inscriptions painted in the heart or on

\footnotetext{
${ }^{1}$ This short note lays the groundwork for further investigation on the inscriptions in the mural paintings of Romanesque Catalonia commenced at the invitation of Milagros Guardia and Carles Mancho. I want to thank them for their welcome in Barcelona and the working conditions they offered me during my visits to the MNAC. A more documented version of this article was presented at the ARS PICTA symposium held in Barcelona in 2012, and the first results will be published in 2016 in a volume directed by Nicolas Reveyron and Diane Daussy on the relations between the medieval building and its decoration.

${ }^{2}$ The doctoral dissertation of Marina Paniagua, started in 2015 at the IRCVM-University of Barcelona, will undoubtedly make valuable progress on these issues.

${ }^{3}$ The bibliography on this subject is considerable; among the titles whose reading is useful, see BeLtinG-IHM 1994; Épigraphie 1996; FaVReau 1988 ; Riccioni 2008. For a wider bibliographic review, I refer to Debiais 2010.

${ }^{4}$ For a development of medieval epigraphy, its purpose, and methods, see Favreau 1995; Treffort 2008a; García Lово1999.
} 
the margins of the image, thus eventually making up a pictorial anepigraphic environment or, in the best- case scenario, a context where the text is reduced to an anecdotal epiphenomenon in the implementation of the decoration, with an insignificant role in the functioning of the image, and transparent to the commentary of art historians. ${ }^{5}$ The major ensembles of medieval mural painting have yet to be studied in their epigraphic dimension and the consideration, edition, and interpretation of painted inscriptions has still much to say about the medieval uses of the painted image.

Let us start with some opening remarks. For obvious preservation reasons, it is very difficult to study the inscriptions in mural painting before the Romanesque period, and most of the conclusions that such a study could draw would inevitably mark the "moment roman" and its formal and aesthetic characteristics. Painted inscriptions do not seem to have enjoyed a greater presence at any specific moment of the medieval period, and the number of Romanesque texts increases more along with the number of Romanesque paintings preserved than because of any Romanesque specificity of painted writings. ${ }^{6}$ The paintings of Saint-Pierre-les-Églises in France (Fig. 2) (CoRpus 1974-2014, 2-1, 28-31), and Reichenau-Oberzell in Germany (Fig. 3) ${ }^{7}$ indeed evidence that there could be inscriptions traced within the image — in the first case —or on its margins - in the second location - in the early Middle Ages. Even earlier, the descriptions of Paulinus of Nola report that inscriptions, sometimes very long, were traced from late Antiquity onwards in the mural paintings of important buildings (GASTON 1969; ENGEMANN 1974; HeRBerT de la Portbarrée-Viard 2006). In the same way, and focusing on the last third of the Middle Ages, Gothic paintings also granted a prominent place to writing, with original arrangements and contents evoking what can also be found in the tapestry of the same period, among other contexts. ${ }^{8}$ Without contradicting such consistency in the use of writing in mural painting, the central period of the Middle Ages, however, displayed the most diverse inscriptions with regard to their location, their form-linguistic and / or palaeographic — and their relationship with the image.

The great French cycles known for France (Saint-Savin, Ébreuil, Saint-Hilaire de Poitiers), but especially the great Italian cycles (particularly Ceri or Vercelli), display writing in a variety of forms and dispositions, sometimes in the same place, ${ }^{9}$ alternating large inscriptions placed in a banner below or above scenes, short texts in contact with the figures, Biblical citations on scrolls, exegetical commentaries around medallions, etc. (Fig 4: Saint-Savin, scene of the Tables of the Law). Painted

\footnotetext{
${ }^{5}$ The controversial work LAVIN 1990 does not mention any inscription when establishing the reading guidelines for the painted cycles.

6 We separate ourselves here from the otherwise excellent conclusions offered by RICCIONI 2008 about a possible epigraphic inflation in the Romanesque period, and the contact of images, for which the effect of the source seems quite remarkable.

${ }^{7}$ On the inscriptions of Reichenau, see BERSCHIN 2005: 215-228.

${ }^{8}$ See the parallel contributions in Gérez 2007.

${ }^{9}$ For a comprehensive view of the different arrangements, see HECK 2010.
} 
writing then becomes part of the image; it punctuates its development, stresses its articulations, and is involved in the visual effect of the decoration within the church (DEBIAIs 2011).

Catalan mural paintings are no exception, even if large inscriptions whose implementation echoes the composition of the decoration are rare. The bands delimiting the scenes indeed include few inscriptions and when they do, for instance in Sant Climent de Taüll (CATALunYA RomÀnica 1994: 323-327), or in Sorpe (Mancho 2000; PAgĖs 2008: 115-142), they are short texts, nominal inscriptions that may be painted closer to the image, as were the vast majority of names painted in different ensembles. How to interpret such alternation of nominal inscriptions inside / outside scenes? We will return to this issue below, the explanation of a lack of space is unsatisfactory - there was enough "room" in Sorpe, in the scene of the Vocation of the Apostle, to draw the name of St. Andrew (Fig 5.). In most cases, it is probably an issue related to the status of the image; extracting the name of a figure from the development of the scene results in a still, stable, and iconic image beyond the narrativity of the visual. In this sense, the different arrangements of nominal inscriptions in the nave of Santa Maria de Taüll are quite significant (CATAlunya Romànica 1994: 327 et sq.): only the names of saints Clement and Michael (Fig. 6), who are depicted in the manner of an iconic portrait, were inscribed in a coloured band serving as "pedestal" to the image. Moreover, when the saint is painted within a narrative scene (St. Michael weighing souls, for example), the name is at the very heart of the image.

The long colour bands that mark the decoration of Santa Maria de Taüll present no inscription, and the epigraphic occupation of the image remains discreet; it is thus necessary to pay particular attention to the decoration of Sant Pere de Sorpe. Next to the Gospel, in the nave, we see a very beautiful panel, in the lower register, representing an incomplete Crucifixion (Fig. 7). The most characteristic element of this ensemble - after all, very classic in its composition - is the angel that appears on the right of the crossbeam of the cross; as Marcello Angheben described (2008), he wears "a stole on his right shoulder and a maniple on the left arm. He dons the clothes that better characterize the officiant when he celebrates Mass." He is identified by a fragmentary inscription painted on the background of the image, and holds a censer next to the crucified, which, always according to M. Angheben, provides a certain liturgical dimension to the scene represented in Sorpe. We can not study this scene and its possible implications without considering the inscription above the Crucifixion, in the triple band that transitions between the meander and the image of the lower register, which occupies the upper part in a band that ensures the association of the inscription with the scene as a whole, and not only with one of the characters in the painting, as was the case with the inscription of the angel or the sponge-bearer. The analysis of the extant fragments of the Crucifixion shows that there was a painted metric inscription, most likely composed of at least one leonine elegiac couplet where the word "plorat" rhymes with "orat." This rhyme is not unknown in Western medieval epigraphy; it is found in funerary inscriptions before the 13th century, but also in several inscriptions in connection with 
images, including some linked to the representation of the cross (Crucifixion and Descent from the Cross). It is found in the famous inscription of Silos: HIC OBIIT HEC PLORAT CARVS DOLET IMPIVS ORAT (GARCíA LoBo 1990) (Fig. 8). Without wishing to weave too strong links between the two images, the Silos cross is also topped by sycophant angels who certainly bear neither stole nor maniple. As in Sorpe, the inscription unites all characters within the same composition in an escalation of deictics. It belongs to a group of texts on which M. Shapiro drew the attention of researchers in 1939 (SchapIro 1939: 364). The composition of Sorpe seems however more complex, particularly due to the use of the word cohors, very rare in medieval inscriptions. It is undoubtedly difficult to include this text as it is in the group formed, among others, by the cover of the Evangeliary of St. Godehard - originally from Hildesheim and now kept in the Cathedral of Trier - on which an angel shows the empty tomb to the holy Women, who come, censers in hand, to pay homage to the body of the Lord, and is accompanied by this inscription: ANGELVS EXILARAT DOMINI QVOS MORS CRVCIARAT (FAVREAU 1997: 98). The inscription painted above the scene of Sorpe places the image in a tradition of compositions supplemented by a special type of inscriptions that overdetermine the role of each character rather than provide the image with an overall and synoptic sense in the context of a large-scale composition.

Looking deeper into painted inscriptions must not lead to cut drastically out the rest of the epigraphic production, nor the other forms of writing present in images. The technique, scale, and function of the decoration of painted places certainly embody some of the contingencies with which these inscriptions should be read. However, inscriptions did not generate an autonomous documentation that can be understood without considering what the Middle Ages established about the theory of the image and the coexistence of alphabetic and iconic signs. ${ }^{10}$ Looking deeper into painted inscriptions must not lead to cut drastically out the rest of the epigraphic production, nor the other forms of writing present in images. The technique, scale, and function of the decoration of painted places certainly embody some of the contingencies with which these inscriptions should be read. However, inscriptions did not generate an autonomous documentation that can be understood without considering what the Middle Ages established about the theory of the image and the coexistence of alphabetic and iconic signs ${ }^{11}$ - which evinces the singular composition of the inscription of Sorpe. The potential specificities of a text are first induced by the particular conditions of implementation of writing in a given image, and only in the second place are they the result of the technique used in the support where the writing is placed. This is why the painted inscriptions share many of their features and their devices with those found in manuscript images, in sculpture, in goldsmithery, etc.

\footnotetext{
${ }^{10}$ On these matters see, in particular, FaVREAU 1992; DeBIAIS 2013a.

${ }^{11}$ On the inscriptions in goldsmithery and for a demonstration of the potential specificity of this type of texts, see BAYER 1996.
} 
Among these common, the writing often shares the "background" of the image without a frame or a cartouche, without a special arrangement of the letters in the decoration; simple inscriptions often provide the identification of the figure next to which they are placed. In Santa Maria de Taüll, this is the case for the texts with the name of the Virgin and St. Michael, on the south wall, or the Magi and peacocks, on the east wall; in Sant Climent de Taüll, the name of the evangelists was drawn in the apse in the same way. This "absence" of devices framing the inscription allows the fusion of writing and image, bringing them together, and merging them completely on the support. In the case of nominal inscriptions, rather than being a basic solution, tracing the text on the background of the image to which it is related without further devices, establishes an equivalence, a sort of equality between the representation through image and the representation through writing; and that's probably why this is the most common form used in Catalan Romanesque mural paintings, and beyond-for instance, this is the only device chosen for the entire vault of the nave of Saint-Savin sur-Gartempe (FAVREAU 1976).

The apparent simplicity of the implementation of such inscriptions with an absent or transparent device has two major methodological consequences: (1) it has often led to believe that the inscription was placed "where possible," where the artist "had room to place it;" (2) it also prevented to look in depth into the coexistence of alphabetic and iconic signs. In short, there was nothing to say about such banal inscriptions and the clear redundancy between the content of the image and the text was definitive proof of their lack of interest... However, many factors oppose this view. On the one hand, the documents show that the presence of writing on an image is never systematic nor obvious; on the other, the status of the sign (and especially, of the alphabetic character) in medieval culture prevents considering their implementation as devoid of meaning; finally, the practical conditions needed for the performance of the decoration imply planning and ordering the different elements that will materialize upon the primer. In other words, the painter introduces an inscription in the image because it generates an effect in the decoration, an effect that lies in the content of the text, in its layout, and in the conditions for its implementation. Accordingly, all texts present in mural painting are relevant to a better understanding of the meaning and intentions of medieval decoration.

Like the inscriptions placed on other supports, the texts in mural painting are related to the image at varying scales, and can involve a figure, a scene, a group of images, the decoration as a whole, or even the building in which it is carried out. ${ }^{12}$ The ecdotic principles of medieval epigraphy favoured a fragmented reading of ensembles of inscriptions, separating inscriptions from one another according to a division into different "notes". In the edition of the inscriptions of the vault of Saint-Savin, the Corpus des inscriptions de la France médiévale presents the texts one after the other depending on their location north or south of the nave, regardless of the cycles

${ }^{12}$ For a consideration of the scale of the building in the implementation of the decoration, see KESSLER 2003; BASCHET, Bonne, DitTMar 2012. 
where they are inscribed and the devices selected to insert them into the image. In the volume of Catalunya Romànica devoted to the MNAC collections, when reproducing the inscriptions of the main mural painting ensembles kept in Barcelona, the authors chose to reproduce texts in a non-systematic manner, at the end of a note or in connection with a particular image, which does not allow to weigh the graphic density of these paintings, or to understand the semantic issues of writing on the image. If the establishment of general principles seems impossible because of the uniqueness of each decoration, the editor of the inscriptions should in all cases propose two different analyses: a first analysis of the details of each inscription that provides all the information about the palaeographic specificities, layout, content, etc.; a second analysis of the whole decoration studying the location and function of epigraphic writing in a given ensemble. This double approach would allow readers to understand the inscription in its context.

The inscription Ego sum lux mundi in Sant Climent de Taüll can thus be read according to these two perspectives (Fig. 9). ${ }^{13}$ At the microscopic scale, looking at the text painted on the book implies first questioning the current state of the paint and noting the thickness of repaintings and restorations; it also involves noticing the particular arrangement of the text, which disregards the depiction of the open codex to represent the inscription on two continuous lines separated by a double line; finally it must consider the particular treatment of blank space on the book, "filled" by a pseudo-epigraphy that recalls the wing feathers of the archangels. Studying the shape of the letters in the book emphasizes the graphic meticulousness, the presence of ornamental pearls on most straight lines, and the alternating stroke thicknesses; it stresses the complexity of connections in the word mundi, and finally implies analysing how the size of the characters expands towards the end of the pages to enhance the effect of the open codex. Reading the text painted on the book leads us to identify the quotation from the Gospel of St. John, and to notice the difference between the quotation and the nature of the representation. It also places the text of Sant Climent de Taüll among many other inscriptions of that same quote that accompany images of Christ in medieval art. At the macroscopic scale the choice of the phrase of the Gospel according to Saint John can be linked with certain iconographic details that draw attention to the centre of the image of Taüll - the six eyes of the lamb of God at the top of the vault are only the most obvious of these details. But it is clear that this second approach at the scale of the decoration cannot be achieved without the first one that establishes the text, describes and appraises its authenticity. The inscription is still composed of several elements, and an epigraphic study must take into account all aspects of the text, its shape, content, and location.

All the endeavours to edit European medieval inscriptions have traditionally favoured one or the other component of the "inscription" system. The Corpus des inscriptions de la France médiévale has particularly focused on the content of the inscription, on its textual dimension; the very recent corpus of medieval Italian inscriptions focused on palaeographic questions and on

${ }^{13}$ On this type of inscriptions, see Favreau 2010; Debiais 2013 b. 
the number and shape of carved or painted signs; the Spanish effort of the Corpus inscriptionium Mediae Aevii Hispaniae is in turn devoted to the "diplomatic" dimension of epigraphic texts. Justifiable and fruitful as they are, these approaches have tended to remove the inscription from its environment - iconic, architectural or archaeological — to produce a crude and independent text without formal or semantic relationship to its surroundings. This is problematic for all types of text, but it is even more so when said environment contains in the images it displays the explanation for the introduction, the layout, and the form of writing. ${ }^{14}$

Medieval inscriptions linked to an image are numerous and concern all supports. In general, the choice of a particular material or a particular form does not allow presuming the content of the text. However painted inscriptions in connection with something other than an image or a scene as a whole are very rare. Inscriptions often bear the name of a character, the title of a scene, the titulus interpreting a composition, or the words spoken by one of the protagonists of the image. Thus, painted writing has been little considered among medieval texts, probably for simple preservation reasons. Painted inscriptions from Roman times with no apparent link to the image are mostly texts in connection with the dedication of a building or the dedication of an altar. The inscriptions of Saint-Chef-en-Dauphiné (Corpus 1974-2014, 17, I 21: 49-50, Fig. 32), Cluny (Corpus 1974-2014, 19, SL 29: 87-88, fig. 110), Cizay-la-Madeleine (Corpus 1974-2014, 24: 120), and Sant Climent de Taüll (Fig. 10) (CAtalunya Romànica 1994: 326) (fig. 10) are the most renowned examples of this practice. How to explain this phenomenon? A simple answer is to consider painting as the most flexible technical means to place text "wherever it is wanted" without having to bring an external object to the construction, without interfering in the work of the chapel or the church. It is however not satisfactory since documents show many of these texts engraved in stone, on an independent place, or directly on the wall of the building. Another explanation is to see the writings painted on a primer as a single layer (which brings together a whole construction), the means of expanding the content of the text to the entire building without limiting it to the the borders of a block of stone or other autonomous element (GAGNE 2010; TREFFORT 2008b).

The continuity of the primer makes it possible to read the epigraphic contents of a given decoration throughout the building that houses it, and not as a series of disjointed inscriptions. In Sant Climent de Taüll always, the fact that the dark band of the circular wall of the apse is also found in the right bay and in the eastern wall for the names of other saints brings thus together all the figures praising the Maiestas Domini on the semi-dome. With no doubt, and irrespective of the recent discovery of the inscriptions on the eastern wall, the edition of the inscriptions of this decoration will separate the names into several groups based on their location or depending on the figures to which they refer. However, the joint reading of the paintings in the eastern part of

\footnotetext{
${ }^{14}$ For an exemplary reading of the relationship between text and image, see ThunO 2011.
} 
the building, leads to conceive the inscriptions as a continuous text, both visually and intellectually, and to incorporate them into a single and expanded ensemble through writing and image.

The understanding of the decorations as a whole should however not hinder the in-depth study of the inscriptions and the analysis of the shape of the letters that compose them. For a number of historiographical reasons, the palaeographic study of inscriptions has been mostly considered from the perspective of the inscriptions engraved in stone - epigraphic characters are by default the Roman capitals incised in stone (Gray 1948; Deschamps 1929; Debiais, Favreau, Treffort 2007). The shapes of painted letters, like those of the inscriptions embossed on metal, or those made of tiles in mosaic, are little known, especially regarding the gestures of the artists and the graphic resources mobilized. The painted ensembles in $12^{\text {th }}$-century Catalonia show very similar scripts from one church to another. It is a mixed script that combines the very straight strokes of Roman capitals and the shapes inspired by Gothic capital letters and their well-rounded forms. Despite appearing more or less elaborate depending on the site, the script is fairly uniform. It presents narrow and little decorated forms, and is mainly characterized by a very pronounced alternation between thick and thinner lines imitating, reproducing, and recalling the opposition between broad and angular strokes of handwriting (Sмith M., Stirnemann 2007). When placed in bands, letters are more homogeneous than when they are painted with no device on the background of the image, as if the band had the ability to "guide" and "stabilize" the shape of the letters - at least in height—by offering a programmed writing space. In all cases, Catalan examples show inscriptions and images whose proportions and chromatic effects match the rest of the composition while the text is at the same time detached from it but integrated into the ensemble.

Inscriptions never seem incongruous or misplaced, and texts do not seem to have been incorporated into the image afterwards. Writing does not overlap with a decoration that would exist without it in a primordial stage or project. The inscription and the image thus belong to a single graphic moment, to the same artistic gesture intended to create a visual product, and seeks to respond to a satisfactory project in both aesthetic and semantic terms. The shape of the letters and palaeographic features are the choice of the master builders of mural painting and obey the same issues regarding composition, consistency, impact, and depiction. ${ }^{15}$ Field data rather accurately respond to what is known about how the paintings were made - the absence of preparatory design for most inscriptions is consistent with the lack of outline for the figures. Caution is also urged in the use of writing for dating painted ensembles; given that the form adopted by the letters is related in nature to the conditions of implementation, and the meaning of the painting in which they are found, the risks of teleological reasoning are remarkable...

${ }^{15}$ On these topics, see Kendrick 1999; JANTZEN 1940. 
One thing is certain: the same creativity is expressed both in the painted figures and in the inscriptions. Alphabetic signs are involved, for example, as much in the visual richness of the apse of the church of Estaon as in the identification of the figures who inhabit it (Fig. 11) (PAGÈs 2005). The intricacy of the letters responds to the density of objects, animals, and creatures painted on the semi-dome. The formal echoes between texts and images are many; they are one and the same visual composition, displayed in the church and offered to the sight of a hypothetical viewer. The analysis of the inscriptions, which too often appears as an option chosen by some zealous researchers, is actually necessary to reflect the reality of painted decorations, especially in Romanesque Catalonia where writing reached an unusual density in the panorama of European medieval art. The inscriptions are also present in 14 out of the 16 painted ensembles kept at the MNAC. These inscriptions include nearly 300 words, a total of 2,500 letters, and epigraphists have there at their disposal one of the richest palaeographic collections of the Middle Ages. 


\section{BibliograPhy}

Angheben, M., 2008. « Théophanies absidales et liturgie eucharistique. L'exemple des peintures romanes de Catalogne et du Nord des Pyrénées comportant un séraphin et un chérubin », Les fonts de la pintura romànica, Barcelona, Publicacions i edicions de la Universitat de Barcelona : 57-96.

Baschet, J., Bonne J.-Cl., Dittmar P.-O., 2012. « Chapitre IV - Notre-Dame-du-Port : un puissant végétalisme et sa relève architecturale », Images Re-vues, Hors-série 3, http:// imagesrevues. revues.org/1865.

BAYER, Cl., 1996. « Essai sur la disposition des inscriptions par rapport à l'image : proposition d'une typologie basée sur des pièces de l'orfèvrerie rhéno-mozane », Épigraphie et iconographie. Actes du colloque tenu à Poitiers les 5-8 octobre 1995, Poitiers, Centre d'études supérieures de civilisation médiévale : 1-25.

Belting-Ihm Ch., 1994. «Zum Verhältnis von Bildprogrammen und Tituli in des Apsisdekoration früher westlicher Kirchenbauten ", Testo e immagine nell'alto Medioevo 15-21 aprile 1993, Spoleto, Centro italiano di studi sull'alto Medioevo : 839-886.

Berschin, W., 2005. Mittellateinische Studien, Heidelberg, Mattes Verlag.

Catalunya Romànica, 1994. Catalunya Romànica, I, Barcelona, Enciclopèdia catalana.

Corpus 1974-2014. Corpus des inscriptions de la France médiévale, Paris : Centre national de la recherche scientifique; Poitiers : Université de Poitiers

DeBIAIS, V., 2010. «L〉écriture dans l>image peinte romane. Questions de méthodes et perspectives », Viator, $41:$ 95-125.

-2011. « Lieu d'image et lieu du texte. Les inscriptions dans les peintures murales de la voûte de la nef de Saint-Savin », L'image médiévale: fonctions dans l'espace sacré et structuration de l'espace cultuel, Turnhout, Brepols : 301-323.

-2013a. " Mostrar, significar, desvelar. El acto de representar según las inscripciones medievales », Codex Aquilarensis, 29 : 169-186.

—2013b. « Au-delà de l'efficacité. Figurer les paroles de Dieu dans les images monumentales romanes », La parole sacrée. Formes, fonctions, sens. Cahiers de Fanjeaux, 47 : 27-48.

Debiais, V., Favreau, R., Treffort, C., 2007. « L'évolution de l'écriture épigraphique en France au Moyen Âge et ses enjeux historiques », Bibliothèque de l'École des chartes, 165 : 101-137. 
Deschamps, P., 1929. «Étude sur la paléographie des inscriptions lapidaires de la fin de l'époque mérovingienne aux dernières années du XII ${ }^{\mathrm{e}}$ siècle », Bulletin monumental, 88 : 5-81

Engemann J., 1974. «Zu den Apsistituli des Paulinus von Nola », Jahrbuch für Antike und Christentum, XVII : 24-46

ÉPIGRAPHIE, 1996. Épigraphie et iconographie. Actes du colloque tenu à Poitiers les 5-8 octobre 1995, Poitiers, Centre d'études supérieures de civilisation médiévale.

Favreau, R., 1976. "Les inscriptions de l'église de Saint-Savin-sur-Gartempe », Cahiers de civilisation médiévale, 21 : 9-37.

-1988. « Peinture et épigraphie. La chapelle du Liget », Peintures murales romanes. Méobecq, Saint-Jacques-des-Guérets, Vendôme, Le Liget, Vicq, Thevet-Saint-Martin, Sainte-Lizaigne, Plaincourault, Orléans, Centre d'études supérieures de civilisation médiévale : 41-50.

-1992. "L'apport des inscriptions à la compréhension des programmes iconographiques », Lecturas de Historia del Arte : 33-50

-1995. Épigraphie médiévale, Turnhout, Brepols.

—1997. «L'apport des inscriptions à l'histoire des anges à l'époque romane », Les anges et les archanges dans l'art et la société à l'époque pré-romane et romane. Les cahiers de Saint-Michelde-Cuxa, 28 : 91-110.

-2010. «Des inscriptions pour l'image du Christ », Qu'est-ce que nommer? L'image légendée entre monde monastique et pensée scolastique, Turnhout, Brepols : 169-185.

GAGNÉ. A., 2010. «L'écriture et la matière dans la construction de l'ecclesia (France, $\mathrm{XI}^{\mathrm{e}}$ XIII ${ }^{\mathrm{e}}$ siècle) », Bulletin du centre d'études médiévales d'Auxerre, 15, 1 : 425-437.

Garcia Lobo, V., 1990. « La epigrafia del claustro de Silos », El románico en Silos. IX centenario de la consagración de la iglesia y claustro (1088-1988), Silos, Abadía de Silos : 85-104.

-1999. " La escritura publicitaria en la Península Ibérica. Siglos X-XIII », Inschrift und Material, Inschrift und Buchschrift. Fachtagung für mittelalterliche und neuzeitliche Epigraphik. Ingolstadt 1997, Munich, Bayerische Akademie der Wissenschaften : 151-190.

Gaston, R.W., 1969. Studies in the Early Christian Tituli of Wall Decoration in the Latin West: the Tituli of St. Paulinus of Nola, Londres, University of London.

Gérez, M., 2007. « Cartouches, phylactères, inscriptions libres : le texte dans les tapisseries de la fin du Moyen Âge », Lecture, représentation et citation : l'image comme texte et l'image comme signe (XI ${ }^{e}$-XVII ${ }^{e}$ siècle). Actes du colloque du 13 décembre 2002, Université Charles-deGaulle-Lille 3, Lille, Université Charles de Gaulle - Lille 3 : 147-169. 
GraY, N., 1948. « The Paleography of Latin Inscriptions in the Eight, Ninth and Tenth Centuries », Papers of the British School at Rome, 16 : 38-171.

Heck, Ch., 2010. «Un nouveau statut de la parole? L’image légendée entre énoncé, commentaire, et parole émise ", Qu'est-ce que nommer? L'image légendée entre monde monastique et pensée scolastique, Turnhout, Brepols : 7-28.

Herbert de la Portbarrée-Viard G., 2006. Descriptions monumentales et discours sur l'édification chez Paulin de Nole. Le regard et la lumière (epist. 32 et carm. 27 et 28), Leiden, Brill.

JANTZEN, H., 1940. « Das Wort als Bild in der frühmittelalterlichen Buchmalerei », Historisches Jahrbuch, 60: 507-513.

Kendrick, L., 1999. Animating the Letter: The Figurative Embodiement of Writing from Late Antiquity to the Renaissance, Columbus, Ohio State University Press.

Kessler, H. L., 2003. " Il ciclo di San Pietro in Valle : fonti e significato », Gli affreschi di san Pietro in Valle a Ferentillo. Le storie dell'antico e del nuovo testamento, Naples, Electa : 77-117.

Lavin, M. A., 1990. The Place of Narrative. Mural Decoration in Italian Churches (431-1600), Chicago, University of Chicago Press.

Mancho, C., 2000. «Les peintures de Sant Père de Sorpe : prémices d'un ensemble presque ignoré», Les hommes et leur patrimoine en Comminges. Identités, espaces, cultures, aménagements du territoire, Saint-Gaudens, Societé des études du Comminges : 545-572.

Pagès i Paretas, M., 2005. « Les pintures romaniques de l'antiga església de Santa Eulàlia d'Estaon : la seva història i la seva cronologia », Urgellia, 15 : 657-683.

-2008. La pintura mural romànica de les Valls d'Àneu, Barcelona, Publicacions de 1'Abadia de Montserrat.

Riccioni, S., 2008. « Épiconographie de l'art roman en France et en Italie (Bourgogne/Latium). L'art médiéval en tant que discours visuel et la naissance d'un nouveau langage », Bulletin du Centre d'études médiévales d'Auxerre, 12

SCHAPIRO, M., 1939. « From Mozarabic to Romanesque in Silos », The Art Bulletin , 21-4: 364.

Smith, M., Stirnemann, P., 2007. « Forme et fonction des écritures d'apparat dans les manuscrits latins (viiie-xve siècle), Bibliothèque de l'École des chartes, 165-1 : 67-100. 
Thuno, E., 2011. «Inscriptions and Divine Presence. Golden Letters in the Early Medieval Apse Mosaic », The Iconicity of Script, Word and Image, $27: 279-291$.

Treffort, C., 2008a. Paroles inscrites. À la découverte des sources épigraphiques latines du Moyen Âge, Rosny-sous-Bois, Bréal.

-2008b. «Une consécration à la lettre. Place, rôle et autorité des textes inscrits dans la sacralisation de l'église », Mises en scène et mémoires de la consécration d'église dans l'Occident médiéval, Turnhout, Brepols : 219-251. 


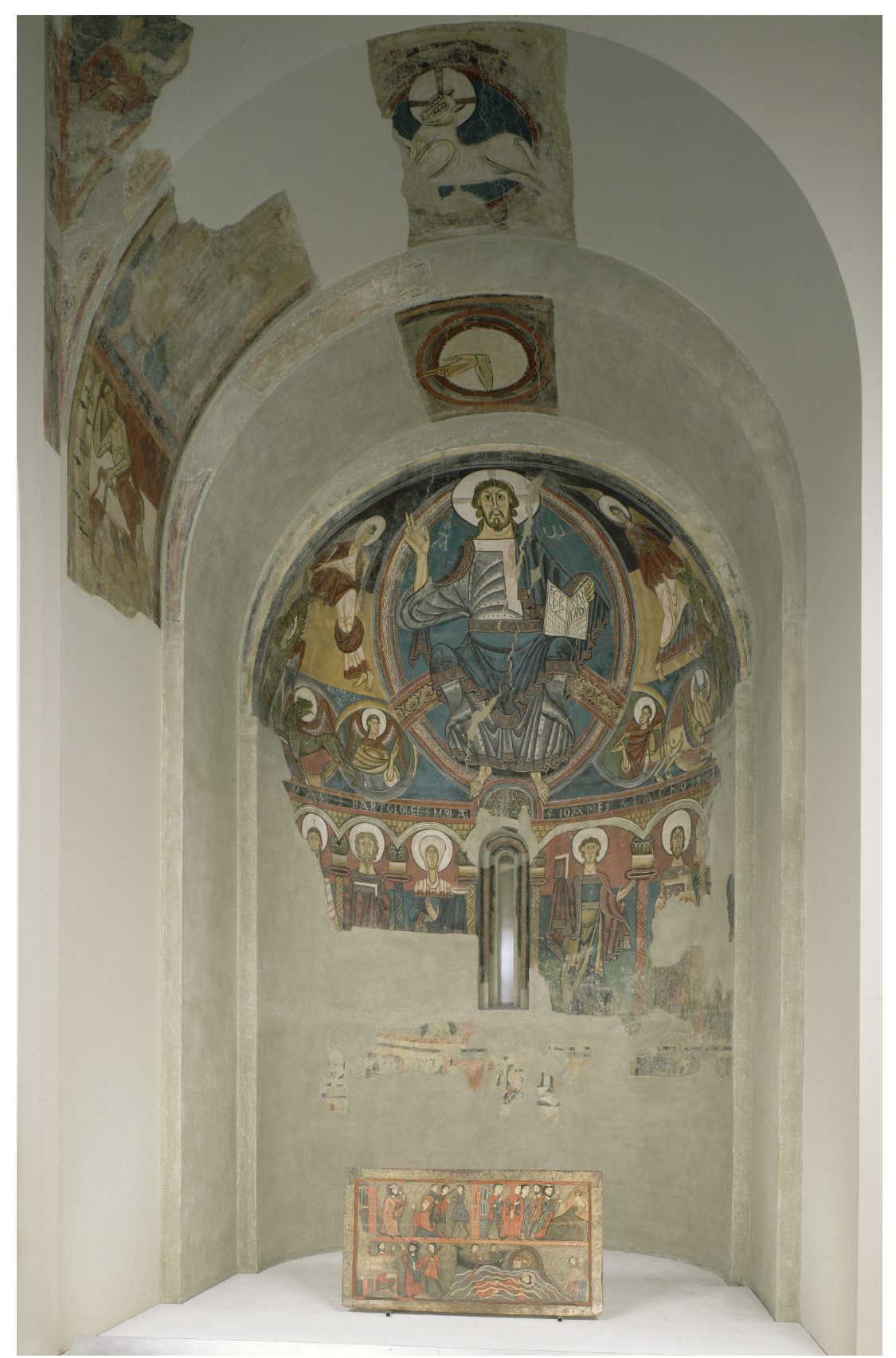

Fig.1: Barcelona, MNAC, mural paintings from the church of SaintClément of Taüll. 


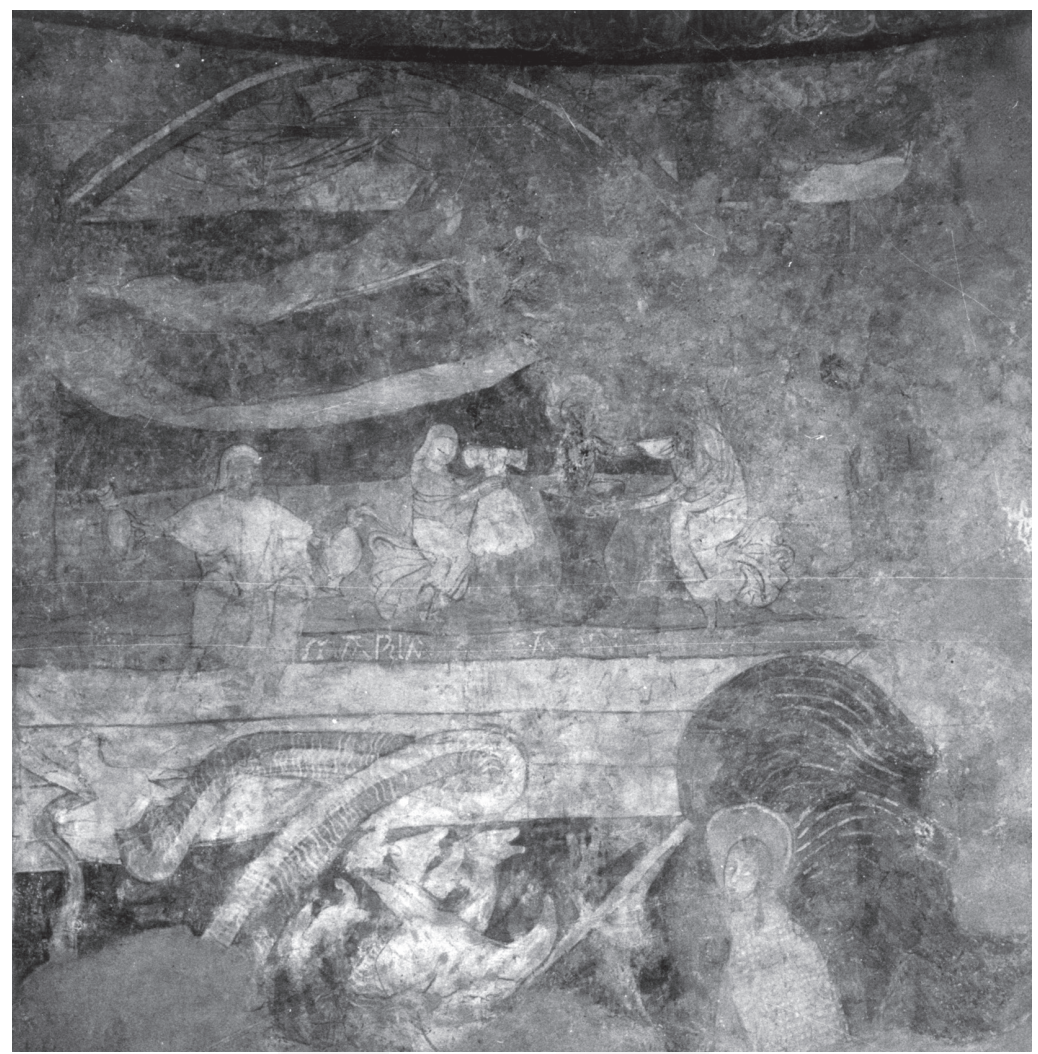

Fig. 2 : Saint-Pierre-les-Églises, apse, Nativity.
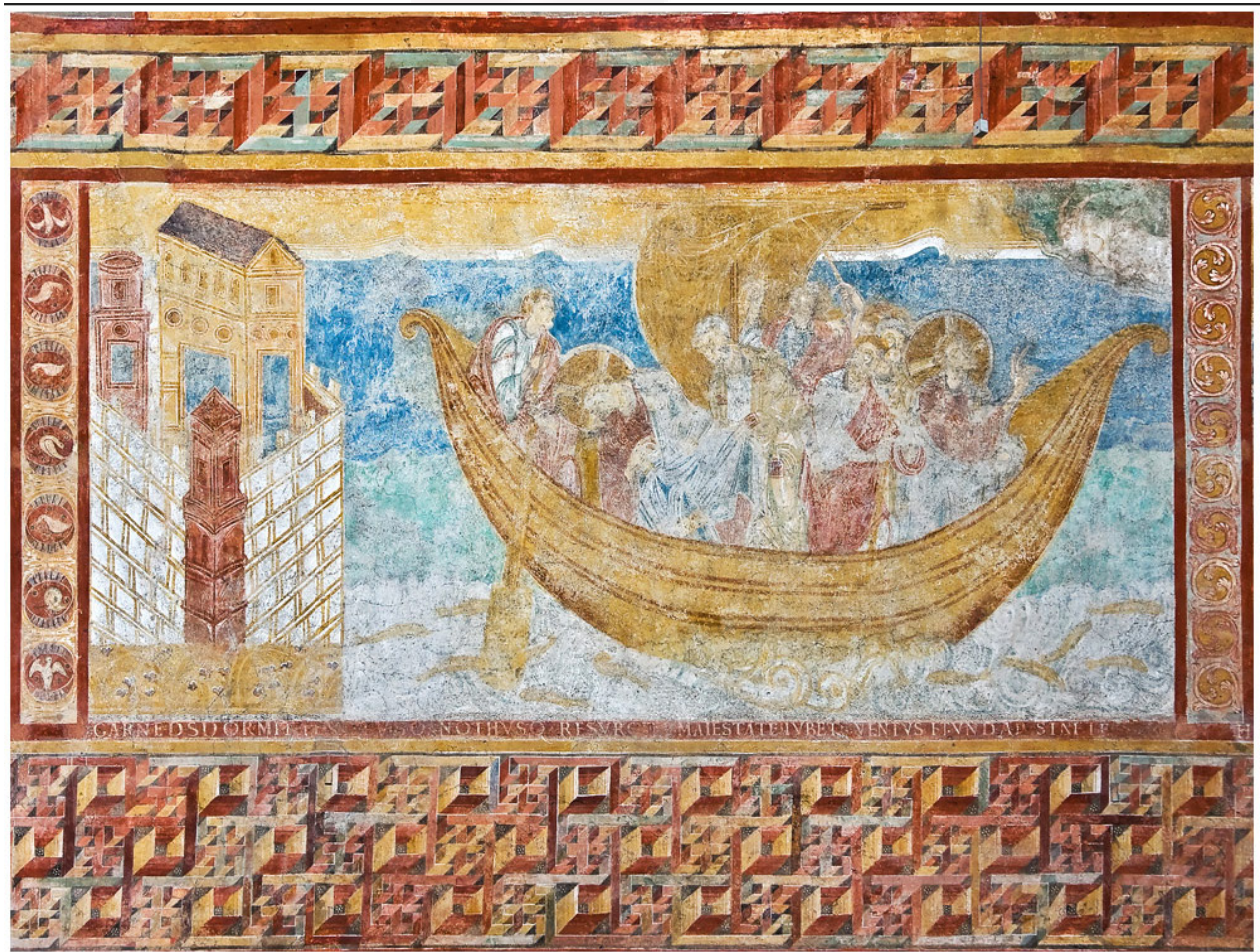

Fig. 3 : Reichenau-Oberzell, church of Saint-Georges, mural paintings in the nave, Jesus stilling the storm. 


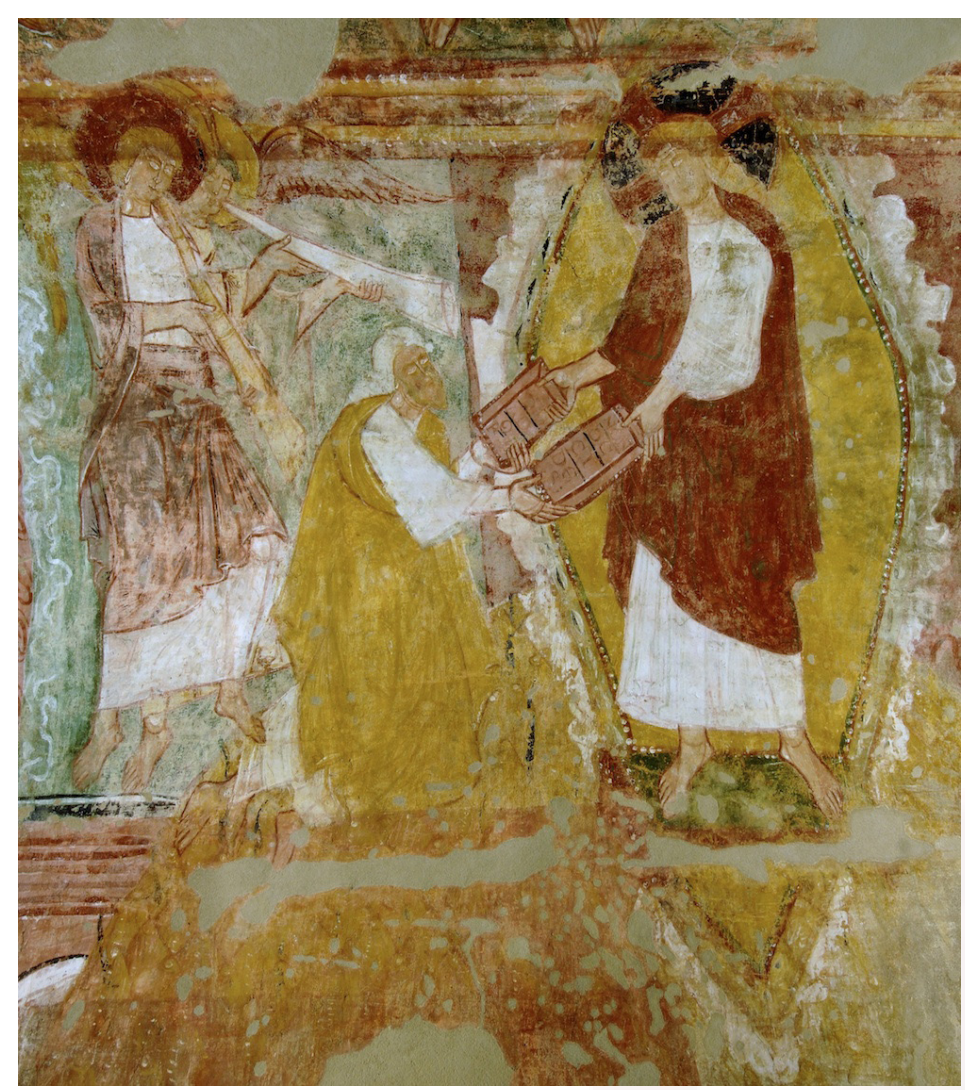

Fig. 4 : Saint-Savin-sur-Gartempe, abbey-church, north side of the nave, Moses receiving the tablets of the Law.

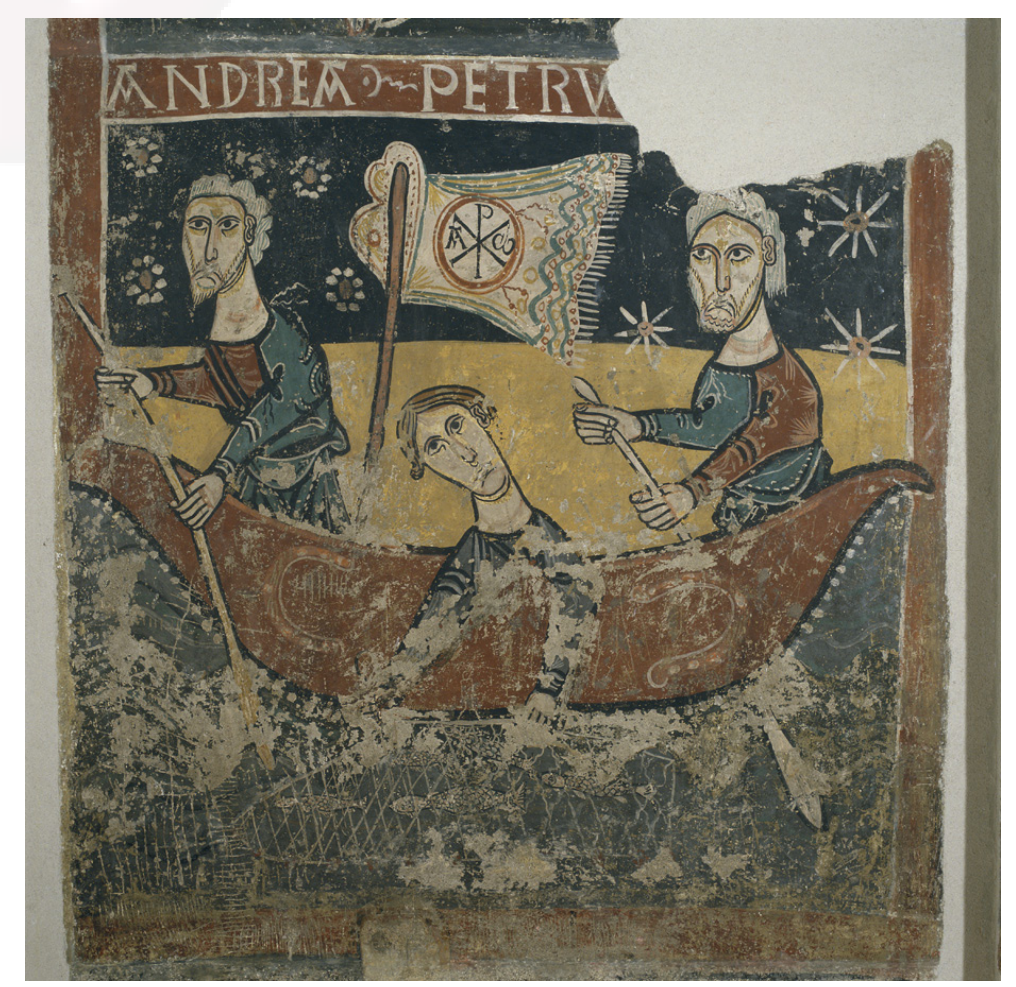

Fig. 5 : Barcelona, MNAC, mural paintings from the church of Saint-Pierre de Sorpe, north wall, calling of the first Apostles. 


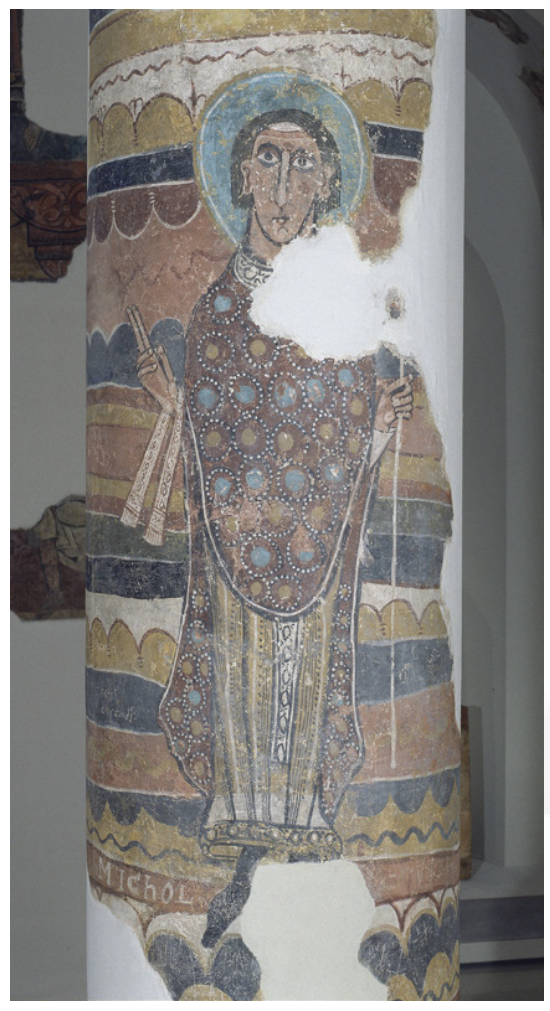

Fig. 6 : Barcelona, MNAC, mural paintings from the church of Sainte-Marie of Taüll, nave, south side, Saint Michael.

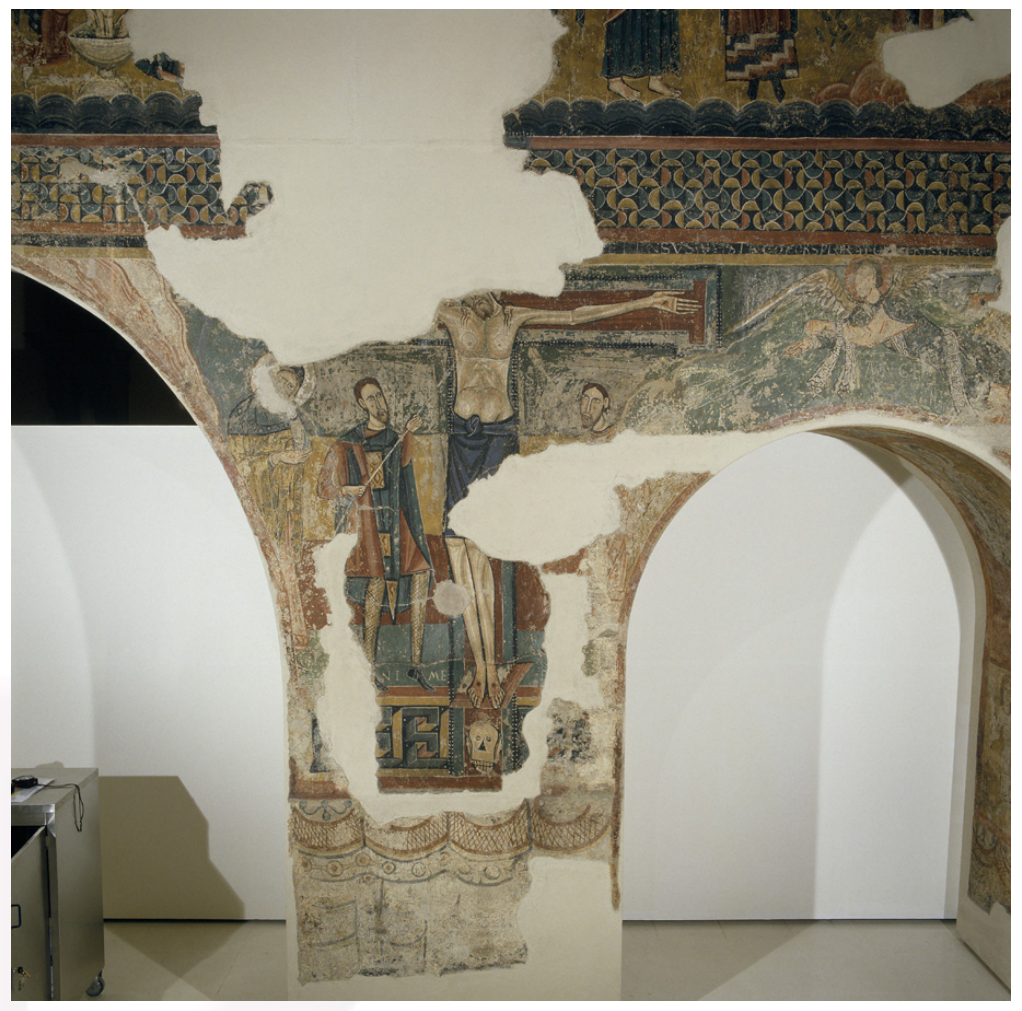

Fig. 7 : Barcelona, MNAC, mural paintings from the church of SaintPierre de Sorpe, north wall, Crucifixion.

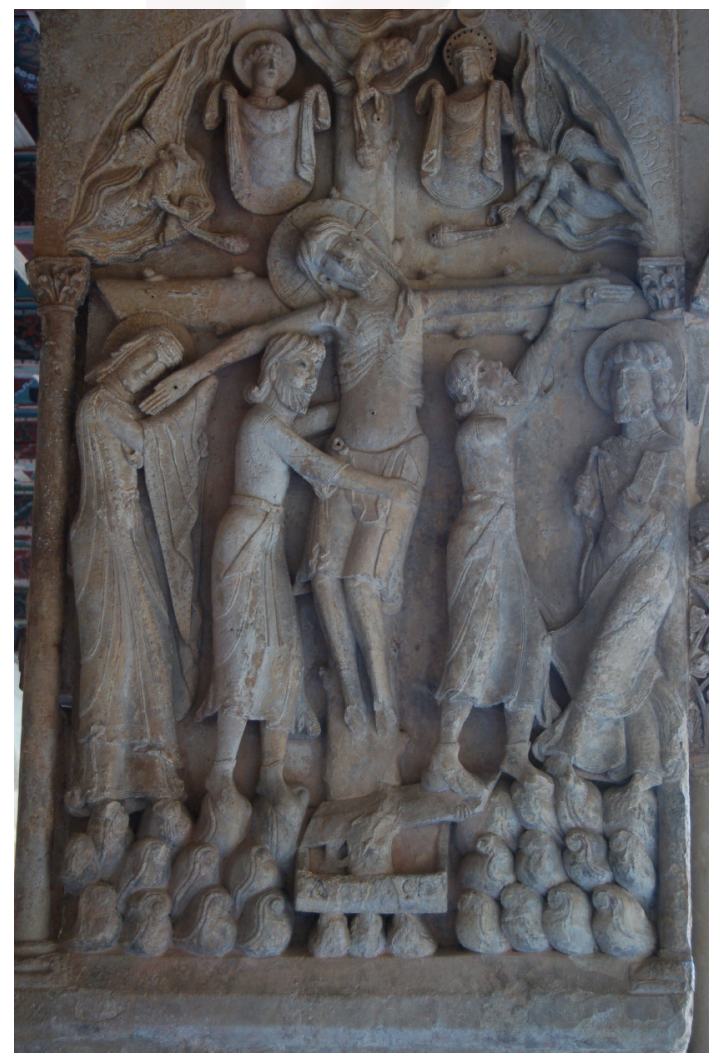

Fig. 8 : Santo Domingo de Silos, abbey, cloister, relief of the Descent from the Cross. 

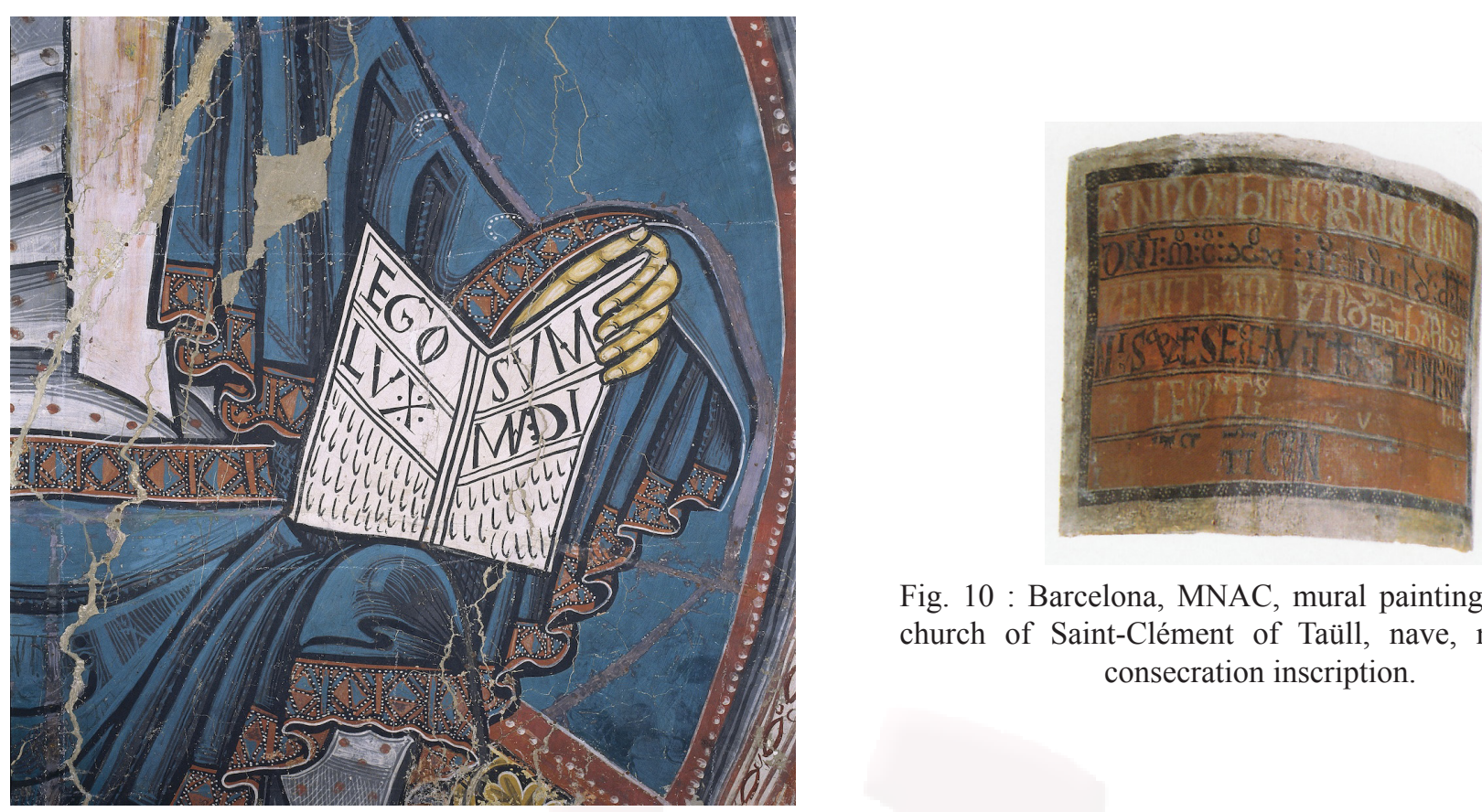

Fig. 10 : Barcelona, MNAC, mural paintings from the church of Saint-Clément of Taüll, nave, north side, consecration inscription.

Fig. 9 : Barcelona, MNAC, mural paintings from the church of SaintClément of Taüll, central apse, book held by a Christ in Majesty.

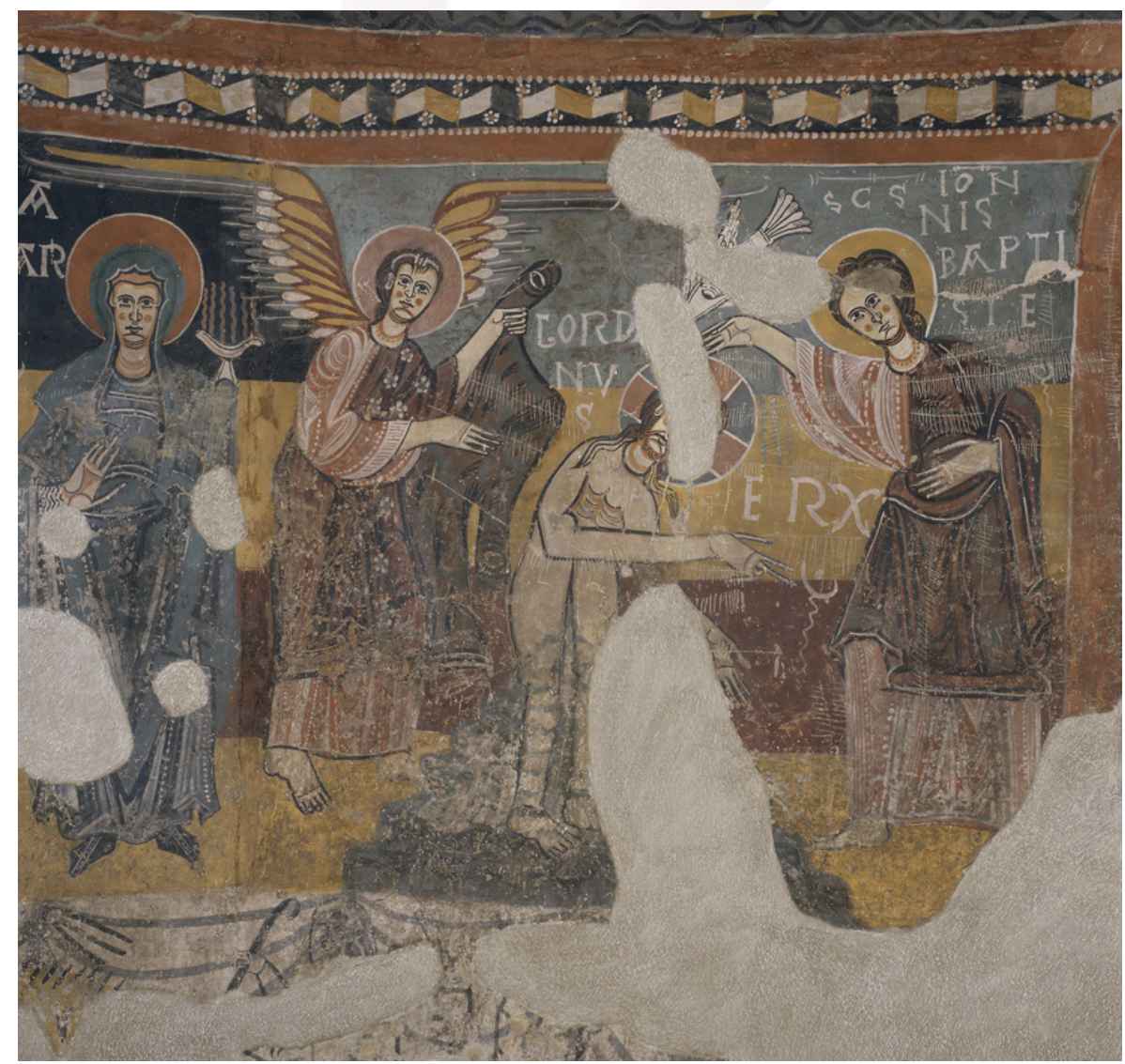

Fig. 11 : Barcelona, MNAC, mural paintings from the church of Sainte-Marie d'Estaon, circular wall of the apse, scene of the Baptism of Christ. 